\title{
A Funerary Stela \\ from the Egyptian Museum \\ (CCG 1753)
}

\section{* Dr. Rasha Farouk El Sayed Mohamed}

The funerary painted limestone stela under study is kept now in the Egyptian Museum, bearing the registration number CCG 1573 (Plate 1). According to the Museum Catalogue, the stela was purchased from Luxor in 1889, its provenance is may be Moaalla, the date of it is broadly Old Kingdom to the Middle Kingdom $^{(1)}$.

\section{Description (Figure 1):}

The stela under study a rectangular limestone with cavetto cornice on its top and a torus-moulding roll. It measures $56 \mathrm{~cm}$ in height, and $34 \mathrm{~cm}$ in width. Although the stela is in a poor state of preservation, but the colors of texts and scenes painted onto its surface are still in a good state; most of these scenes have black outlines except the outlines of the man and woman that carved in sunk relief. The stela is divided into three registers: the upper register comprises the main text, the middle one depicts by the main scenes of the standing human figures ${ }^{(2)}$, offerings, and four short

* Assistant Professor -History and Egyptian Archeology- Faculty of Arts Alexandria University

* I am grateful to the General Director of the Egyptian Museum for supporting my research on this stela, and for granting me the permission to publish it

( $\left.{ }^{1}\right)$ L. Borchardt, Denkmäler des Alten Reiches, Teil II (CG 1542-1808), Kairo, 1964, p. 176; as for the provenance, see: p. 20.

$\left.{ }^{2}\right)$ R. Freed classified the painted stelae with standing human figures, particularly those coming from Thebes, in her first and second stelae workshops. Both workshops were possibly established in the Eleventh Dynasty and continued into the Twelfth Dynasty. For more information, see: R. Freed, Stela Workshops of Early Dynasty 12, in P. Der Manuelian \& R. Freed (eds.), Studies in Honor of William Kelly Simpson, Vol. 1, Boston, 1996, pp. 299-306, 334. 
texts, and finally the lower register is divided into two different scenes.

As for the cavetto cornice ${ }^{(1)}$, the colors of its parallel fronds leaves are repeated without order in various colors, including white, yellow, red and blue. The white color is only repeated for five times, while the other colors one are repeated for four times. The trace of black color on the torus-moulding which is made of granite suggests that if it was completed, it would have taken its original shape ${ }^{(2)}$.

\section{Upper Register:}

The upper register is covered by three horizontal lines of painting hieroglyphs with an offering formula. It reads as follows:

(1) Htp di nsw Wsir nb Odw \{di.f\} nTr aA nb AbDw (2) di.f prt-xrw tA Hnqt $x A$ kA (w) Abd (w) Ss mnxt xt nbt nfrt (3) wab(t) anx(t) nTr m n kA imAx\{t\}

"An offering that the king gives ${ }^{(a)}$ (to) Osiris ${ }^{(b)}$ lord of $\odot \mathrm{dw}^{(\mathrm{c})}\left\{\right.$ he may give $\left.{ }^{(\mathrm{a})}\right\}$ the great $\operatorname{god}^{(\mathrm{d})}$. Lord of $A \mathrm{bDw}{ }^{(\mathrm{e})}$, he may give $\mathrm{g}^{(\mathrm{g})}$ an invocation offering (of)

(1) The cavetto cornice shape is a standard pattern in the Old Kingdom and is found in many Egyptian false doors, funerary stelae, pylons, and on walls. The characteristic hollow, quarter-circle shape is perhaps derived from the appearance of the top of fronds vegetation used in predynastic huts, before the emergence of mud-brick, stone, or architecture. W.F. Pertie, Egyptian Decorative Art, London, 1920, pp. 98-100, I. Shaw \& P. Nicholson, The British Museum Dictionary of Ancient Egypt, Cairo, 1997, p. 63. For more examples, see: W. Budge, HTBM, Parts I-II, London, 1911-1912, I, P1. 33(BM 82); II, Pl. 1(BM175); H.M. Stewart, Egyptian Stelae, Reliefs and Paintings from the Petrie Collection, Part I, Warminstar, 1976, Pl. 14, 1. For another type, see: E. Brovarski, An Unpublished Stelae of the First Intermediate Period in the Oriental Institute Museum, JNES, 32, 1972, pp. $459-460$

$\left({ }^{2}\right)$ It is like a bundle of reeds bound together and lashed horizontally near the top of the wall and vertically at the corners of predynastic huts to support and preserve them from breaking away. Such construction was an ugly necessity at first, but when stone working arose it had become so familiar that it was faithfully copied in stone as a decoration especially in funerary stelae. W.F. Petrie, op. cit., pp. 97-98; S. Ceorke \& R. Engelbach, Ancient Egyptian Construction and Architecture, New York, 1990, pp. 5-6; for examples with cavetto cornice, see: T.G. Allen, Egyptian Stelae in Field Museum of Natural History, Chicago, 1936, Pls III-IV. 
bread, bear, a thousand of ${ }^{(\mathrm{h})}$ oxen fowl, albaster, cloth $^{(\mathrm{i})}$, and everything good and pure that the god lives on $\mathrm{it}^{(\mathrm{j})}$, for the spirit of the honored one ${ }^{(\mathrm{k})}$.

\section{Notes on the Translation:}

(a) The Htp di nsw formula with sign order $\mathrm{nsw}-\mathrm{Htp}-\mathrm{di}$, as mentioned here, is most common from the Old Kingdom until the end of the Thirteenth Dynasty. The majority of the abovementioned formula shows another sign-order nsw- di-Htp, but without any change in the meaning of the offering formula ${ }^{(1)}$.

(b) The absence of the determinative in the name of Osiris is usually noted at the end of the Twelfth Dynasty $^{(2)}$.

(C) The reduplication of the sign $\square_{\text {in }} 1$ of $\Longleftarrow$ occurred from the late Twelfth Dynasty,

( $\left.{ }^{1}\right)$ W. Barta, Aufbau und Bedutung der altägyptischen Opferformel, ÄGFO, 24, Glückstadt, 1968, pp. 261-262; P. Vernus, Sur les graphies de la fomule "l' offrande que donne le roi" au Moyen Empire et à la Deuxieme Période Intermediairé, in : S. Qiurke (ed.), Middle Kingdom Studies, New Malden, 1991, pp. 141-152; D.Franke, Middle Kingdom Offering Formula, JEA, 89, 2003, pp. 54-55; A. llin - Tomich, Changes in the Htp-di nsw Formula in the Late Middle Kingdom and the Second Intermediate Period, Zäs, 138, 2011, pp. 20-34. As for the different discussions about this formula and the special case of the god Osiris, see: W. Barta, op. cit., pp. 261-262; G. Lapp, Die Opferformel des Alten Reiches, Mains, 1986; pp. 28-29, 30 ff; W. Barta, Zur Bedeutung der opferformel in Alten Reich, GM, 96, 1987, pp. 7-9: D. Franke, op. cit., pp. 3957.

$\left(^{2}\right)$ C. J. Bennett, "Growth of the Htp-di-nsw Formula in the Middle Kingdom", JEA, 27, 1941, p. 78; H. Satzinger, Beobachtungen zur Opferformel Theorie und Praxis, Lingua Aegyptia, 5, 1997, p. 185. For an example from the Theban area during the reign of Amenemhat I, see: D. Franke, The Good Shepherd Antef (Stela BMEA 1628), JEA, 93, 2007, pp. 149, 150, fig. 1; For examples from later periods, see: A. Amer, the Stela of the Herdsman Pepi, JEA, 81, 1995, Pl. XVI; M. Atallah, "Eine Stele dem Mitteren Reich in Ägyptischen Museum Kairo", in: K. Daoud \& others (eds.), Studies in Honor of Ali Radwan, CASAE, 34, Vol. 1, 2005, pp. 157ff. 
when four formulas out of six have it ${ }^{(1)}$. The first additional feminine ending $\square$ after the determinative occurred from the late Eleventh Dynasty $^{(2)}$.

(d) The stela orthography of $\odot d w$ must be wrong due to the insertion of $\simeq$ which is meaningless in it.

(e) The horizontal sign $\rightleftharpoons$ of the epithet $\mathrm{nTr}$ aA is first attested in the Eleventh Dynasty ${ }^{(3)}$; this orthography continued to be in use during the Twelfth Dynasty and Thirteenth Dynasty ${ }^{(4)}$.

(f) The feminine ending $t$ after the determinative, like C) $\mathrm{dw}^{(5)}$.

(g) As for di. $f$ in the phase di. f prt xrw, according to the Bennett-Satizinger dating system, no examples of it were attested in the Eleventh

( $^{1}$ ) C.J. Bennett, op. cit., pp. 78-79; M. Collier \& B. Manley, How to Read Egyptian Hieroglyphs: A Step-by-step Guide to Teach Yourself, London, 1998, p. 41. For examples from stelae, see: T.G. Allen, op. cit., p. 16; W. Budge, HTBM, Part II, London, 1912, p. 8, P1. 12 (BM 581); and from coffins, see: G. Lapp, Typologie der Särge und Sargkammern von der 6. bis 13. Dynastie, Heidelberger, 1993, Blätter, 17, 35; J. Taylor \& N. Strudwirck, Mummies: Death and the Afterlife in Ancient Egypt: Treasures from the British Museum, London, 2005, p. 45.

( $\left.{ }^{2}\right)$ W. Schenkel, Frïhmittelagyptische Studien, Bonn, 1962, p. 40, § 10.d. For a further example, see: D. Franke, The Good Shepherd, p. 152, fig. 1.

$\left(^{3}\right)$ W. Schenkel, op. cit., p. 30, § 4, C; H. Selim, Three Identical Stelae from the End of the Twelfth or the Thirteenth Dynasty, $\boldsymbol{S A K}, 29,2001$, p. 325, b.

$\left({ }^{4}\right)$ For more examples from the Twelfth Dynasty, see: W. Schenkel, op. cit., pp. 3013; L. Azzam, Stela of Intef., Journal of Faculty of Archaeology at Qena, South Valley University, 6, July 2011, p. 102, fig. 1, and from Twelfth or Thirteenth Dynasty, see: H. Selim, op. cit., pp. 320-322, figs. 1-3 (CCG 20684, TN 30.10.17.5, TN 18.4.22.3). It is worth noting that the same word-order of our Osiris formula with nb CdwnTr aAnb AbDw occurred in stelae CCG 20234, 20605 dating back to the Middle Kingdom, see: H. Lange \& H Schäfer, Grabe-und Denksteine des Mittleren Reiches in Museum von Kairo, Berlin, Teil I, 1902, p. 255; Teil II, 1908, p. 243.

$\left({ }^{5}\right)$ For an example of the same ending $\mid$ in both $\odot d w$ and AbDw, see: D. Franke, the Good Shepherd, p. 152, Fig. 1. 
Dynasty, but numerous examples of it are more evident toward the end of the Twelfth Dynasty ${ }^{(1)}$.

(h) The writing of the $x A$-sign is unusual ${ }^{(2)}$, and $x A$ which means "thousands of" is found prior to the Twelfth Dyn-asty. ${ }^{(3)}$

(i) $\Perp \gamma_{\mathrm{Ss}}$ mnxt is may be prior to the reign of Senwosret III, due to the epigraphy $\stackrel{\gamma}{\Perp}$, which is attested from the last reign ${ }^{(4)}$.

(j) This phrase is found very often before the Twelfth Dynasty and the addition of anxt nTr (i)m appears for the first time during the reign of King Amenemhat I or Senwosret I or both of them ${ }^{(5)}$.

(k) Bennett suggested that this phrase $n k A(n)$ imAx, appeared during the reign of King Amenemhat II. He concluded that in the Eleventh

( $\left.{ }^{1}\right)$ C.J. Bennett, op. cit., pp. 77-78; Idem., Motifs, and Phrases on Funerary Stelae of the Later Middle Kingdom, $\boldsymbol{J E A}, 44 ; 1958$, p. 121; C. Obsomer, i. f prt $\mathrm{xrw}$ et la filiatiom ns ( $t)$. n/ir ( $t)$. n comme critères de datation dans les textes du Moyen Empire, dans C. Cannuyer et al, Individu, société et spiritualité dans I'Égypte pharaonique et copte. Mélanges égyptologiques offerts au Professeur Aristide Théodoridès, Bruxelles, Mons, 1993, pp. 170 ff; H. Satzinger, op. cit., p. 185. For examples, see: H. Selim, op. cit., pp. 320-322 figs 1-3. In this case and after Leprohon's mention to the addition of di xrw to the offering formula which may have been occasioned by the reinterpretation of the text of the Twelfth Dynasty, Spanel commented that "If the offerings were no longer jointly given by the king and Anubis or Osiris to the deceased but by the king to the deity in order that the latter in turn give them to the deceased, then the prospective di.f (with resultative or optative nuance) was no doubt added to make this redistribution clear". D. Spanel, Palaeographic and Epigraphic Distinctions between Texts of the So-called First Intermediate Period and the Early Twelfth Dynasty, in: P. Der Manuelian \& R. Freed (eds.), Studies in Honor of William Kelly Simpson, Vol. 2, Boston, 1996, p. 769, n. 13.

$\left(^{2}\right)$ For another unusual writings of $x A$-sign from the end of Twelfth or Thirteenth Dynasty, see: H. Selim, op. cit., pp. 326, 6, 330.

$\left(^{3}\right)$ D. Spanel, op. cit., p. 770 .

(4) A. Llin-Tomich, op. cit., p. 21, 21; n. 11; cf. H. Selim, op. cit., pp. 320-321, figs. 12; for various translation of Ss, see: D. Spanel, op. cit., pp. 768, 769, n. 14.

( ${ }^{5}$ ) C.J. Bennett, Growth, p. 80; Idem., Motifs, p. 121; D. Spanel, op. cit., p. 770, n. 17; 17; for the date of both of Amenemhat I and Senwosret I, see: H. Selim, op. cit., p. 326, n. 13; for example, see: CCG 20234; H. Selim, op. cit., pp. 325-326. 
Dynasty, and usually in the reign of Sesostris I, the

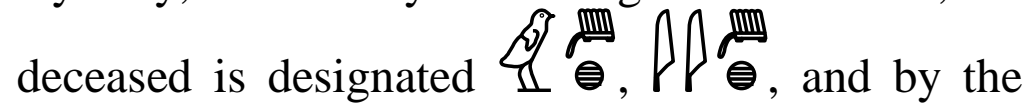
time of Amenemhat II mm $\mathrm{it}^{(1)}$. The $\triangle$ sign in this title to explain as feminine ending if the man, who occupies the center of the second register, is the owner of this stela. I would like to suggest that the name of the deceased and may be the mAa-xrw epithet are to be placed after imAx in the space, which is left by the maker without writing.

\section{Middle Register}

\section{(A) Scenes:}

Standing Human Figures: The man, who occupies the central part of this register, is may be the owner of this stela as he seems traditionally to be larger than the other two figures in the scene. He is standing on a rectangular base painted in black ${ }^{(2)}$, facing the right and receiving an offering. Some details of his face are shown like a large almond-shaped eye, a large pointed nose and a mouth with thick lips ${ }^{(3)}$. He wears a cap wig, leaving the ear uncovered, and his skull takes the elongated shape ${ }^{(4)}$. He wears a long white kilt which is

(1) C.J. Bennett, Growth, P. 79; A. Llin-Tomich, op. cit., p. 26; cf. H. Selim, op. cit., p. 326.

$\left(^{2}\right)$ For examples from the Middle Kingdom particularly the end of the Twelfth or the Thirteenth Dynasty, see: H. Lange \& H. Schäfer, op. cit., PL. XVIII (CC G 20234); L. Borchardt, op. cit., PL. 80 (CCG 1597); H. Selim, op. cit., pp. 320-322, figs. 1-3, 329.

$\left({ }^{3}\right)$ For examples: CCG 1597, see note (18); W. Budge, HTBM, Part II, p. 9, PL. 29. (BM 308).

$\left({ }^{4}\right)$ For the type of elongated skull, see: R. Freed, op. cit., pp. 323-326. The ancient Egyptian men preferred to show their natural hair and leave it short, especially when they wore wigs. Elite men were rarely depicted with their natural hair exposed, but this did not mean that they were never depicted with their natural hair. L. Green, Hair Style, in: D. Redford (ed.), The Oxford Encyclopedia of Ancient Egypt, Vol. 2, Oxford, 2001, pp. 73-74. For examples of cap wigs, see: H. Selim, op. cit., pp. 320-322, figs 1-3; and for natural hair took the shape of cap, see: A. Amer, op. cit., PL. XVI, 3. 
tied above his waist and reaches below the knees ${ }^{(1)}$, and a narrow black collar. He holds a scepter with his right hand which passes behind his figure and a staff with the left hand. A woman is standing behind the man on another low rectangular base painted in black, but was not in the same level ${ }^{(2)}$. She clasps the man's right hand with her left hand. Her face takes the same details of the man's face. She wears a long wig without lappet, with her hair swept behind the ear ${ }^{(3)}$; a narrow black collar; and a long wrap-around dress without shoulderstraps with is painted in white ${ }^{(4)}$. On the right side of the scene, a young woman stands. She is depicted on smaller scale (than the other woman on the left side), floating in midair ${ }^{(5)}$. Her details of face, wing, dress and collar take the same shape of the other woman. She presents a bowl painted in brown to the man with her right hand, while her left hand is not visible.

The Kinds of Offerings: The middle register displays a large number of offerings from different kinds and a wide variety of jar shapes which are not

$\left(^{1}\right)$ For the opinion that the same shape of garment is an apron, and the different between apron and kilt, see: G. Vogelsang-Eastwood, Pharaonic Egyptian Clothing, leiden, New York, Köln, 1993, pp. 32 ff, 41, fig. 3: 12.

$\left(^{2}\right)$ For examples, see H. Selim, op. cit., pp. 320-322, figs. 1-3.

$\left(^{3}\right)$ Although this shape of wig without lappet was not as famous as other shapes, women wore it from the Sixth Dynasty till the end of the Middle Kingdom. For hair and wig in general, see: H. Lange \& H. Schäfer, op. cit., CCG, Teil IV, Pls. LXV-LXVIII; L. Green, op. cit., pp. 117-118; J. Fletcher, Hair and wigs, in : Nicholson \& I. Show (eds.), Ancient Egyptian Materials and Technology, Cambridge, 2000, pp. 495ff. For examples without lappet, see: R. Hölzl, Relifes und Inschrif-tensteine Des Alten Reiches I, CAA, 18, 1999, pp. 48, 54; E. Brovarski, The Inscribed Material of the First Intermediate Period from Naga-ed-Dêr, I, Chicago, 1989, p. 224; CCG 1597, 20334, see note 18; D. Franke, op. cit., p. 16, fig. 4.

( $\left.{ }^{4}\right)$ See: G. Vogelsang-Estwood, op. cit., pp. 96, 100, fig. 7: 3(a), 101.

$\left(^{5}\right)$ A commonly used feature on funerary stelae from First Intermediate period to the end of the Middle Kingdom, see: E. Brovarski, Inscribed Material, p. 677; Unpublished Stele, p. 462, fig. 5 (Louvre C198); L. Azzam, Stela of IAm Ppii, in O. El- Aguizy \& M. Sherif (eds.), Echoes of Eternity, Studies presented to Gaballa Aly Gaballa, Wiesbaden, 2010, p. 59, fig. 1; L. Borchardt, op. cit., p. 110, Pl. 86 (CG 1649); H. Lange \& H. Schäfer, op. cit., II, p. 255, PL. XLIX (CG 20615), p. 381, PL. LVII (CG 20747). 
arranged in order but are distributed loosely around the personal figures to fill the empty space. This feature appeared from the end of the reign of Senwosret $\mathrm{I}^{(1)}$. The offerings include a plucked goose painted in grey and outlined in $\mathrm{red}^{(2)}$; a foreleg of an $\mathrm{ox}^{(3)}$; a calf's head; a rib ${ }^{(4)}$; a bunches of onions and leeks(?) painted in green and outlined in red, except the bunch of leeks(?) which is left incomplete ${ }^{(5)}$; a lotus flower painted in green and outlined in black. The flower has a strange dotted stem painted in black that I do not know any equivalent for $\mathrm{it}^{(6)}$; two round loaves of bread painted in grey with small black dots and outlined in red; six conical loaves of bread painted in yellow; its bases, tops and outlines painted in black $^{(7)}$; and two ovoid shaped jars painted in blue and outlined in black,

( $\left.{ }^{1}\right)$ R. Freed, op. cit., p. 326; for examples from the Middle kingdom CCG 2023, 20615, 20747, see: footnotes $(23,25)$; from Rizeiqat CCG 1597, see: footnote (23); H. Selim, op. cit., pp. 221-223, figs 1-3.

$\left({ }^{2}\right)$ Goose is so important in ancient Egyptian religion, mythology and funerary offerings. The ancient Egyptians distinguished between several varieties of geese, but ornithologists can not equate with certainty these names with modern species. W. Darby \& Others, Food: The Gift of Osiris, Vol. I, London, New York, 1977, pp. 284-286.

$\left({ }^{3}\right)$ For the foreleg as a joint marked $\mathrm{xpS}$, see: S. Ikram, Choice Cuts: Meat production in Ancient Egypt, OLA, 69, 1995, pp. 50-51, 123, 125 fig. 34, 129.

$\left({ }^{4}\right)$ Ribs, which are divided into four groups or more, are shown on offering tables or in the hands of offering-bearers, also in the foundation deposits of temples. S. Ikram, op. cit., p. 127.

$\left({ }^{5}\right)$ For the earliest linguistic record for leek as iAqt from the Sixth Dynasty, and about problem between leek and kurrat, see: L. Keimer, Die Gartenpflanzen im alten Ägypten, II, Herausgegeben von R. Germer, Mainz am Rhein, 1984, p. 59; P. Nicholson, \& I. Shaw, op. cit., p. 630.

$\left({ }^{6}\right)$ For the motif of the lotus flower, its various colors, and its connotations of rebirth, see: Ph. Derchain, Le Louts, La mandragore et le perséa, $\boldsymbol{C d} \boldsymbol{E}, 50,1975$, pp. 65-86 ; W. Darby \& Others, op. cit., Vol. 2, pp. 620-629, 633.

$\left(^{7}\right)$ For examples of the same horizontal group from the Middle Kingdom see: H. Lagne \& H. Schäfer, op. cit., II, Pls XVIII (CCG 20234), XXXII (CCG 20462), XLIX (CCG 20615), particularly from the Twelfth Dynasty, see: W. Budge, HTBM, II, p. 8, PL. 19 (BM 143); for the vertical group, see: W. Budge, HTBM, IV, p. 7, PL. 12 (BM 170); for different kinds of bread, see W. Darby \& Others, op. cit., Vol. II, pp. $517 \mathrm{ff}$. 
supported on the rectan-gular base between the man and his staff ${ }^{(1)}$.

\section{(B) Short Texts:}

1- There are two vertical columns between the man and his staff:

\section{(a) Iqbr (b) ir (n) $\mathrm{IbH}$}

\section{IQbr (a) born (to) IbH (b)}

These (a) and (b) are not understandable: (a) may refer to the man's name, and (b) to the man's father due to ir which means "born"(2). If those are correct according to the study of Obsomer, type $A$ ir ( $t)$. $n$ $B$ (father), is noted from the Thirteenth Dynasty onwards ${ }^{(3)}$. It is worth noting that I did not find any of these names IQbr and IbH neiher in H. Ranke, PN I or D. Franke, Personendaten ${ }^{(4)}$.

(2) There is a vertical column in front of the woman:

\section{an (.i?) anxw}

( $\left.{ }^{1}\right)$ The ovoid shaped jars which are attested frequently in the Middle Kingdom were used for serving the beer and wine, for examples without stoppers, see: W. Budge, HTBM, II, p. 10, PL. 39 (BM 287); T. Allen, op. cit., p. 16, PL IV (31649); and with stoppers from the Twelfth Dynasty, see: W. Simpson, The Terrace of the Great God at Abydos: The Offering Chapels of Dynasties 12 and 13, New Haven and Philadelphia, 1974; Pls. 10 ANOC 4.1 (Louvre C 167), 39 ANOC 26.1 (BM 557) 2 (BM 247) 3 (CCG 20558); L. Azzam, Stela of Intef, pp. 94, a, 100, P1. 1.

$\left(^{2}\right)$ M. Collier \& B. Manley, op. cit., p. 71.

$\left({ }^{3}\right)$ For various types, see: C. Obsomer, op. cit., pp. $170 \mathrm{ff}$; for examples and comment, comment, see: H. Selim, op. cit., pp. 320-322, figs. 1-3, 325, 327.

( $\left.{ }^{4}\right)$ D. Franke, Personendaten aus dem Mittleren Reich, Wiesbaden, 1984. 
This name an(.i?) anxw is known for men from both the Old and the Middle Kingdom, and also for women from the Middle Kingdom only ${ }^{(1)}$.

(3) A feminine name Ib ir is written in two positions: the first Ib is written between the foreleg of the ox and the calf's head and the second ir between the calf's head and the man's staff. However, I did not find this feminine name in $\mathrm{H}$. Ranke, $\boldsymbol{P N}$ I.

\section{Lower Register:}

The lower register consists of two different scenes, the first of which depicts four water pots with flat bottoms standing on an offering table from $\mathrm{wDHw}$ type. The pots are painted in reddish brown; two of them are with stopper in this form $\checkmark$ painted in black and the other two have round lids ${ }^{(2)}$. As for the second scene which depicts an unusual tree painted in green and outlined in black, it should be noted that the tree, in modern times, is marked with the word "faux". H. Selim has pointed out in a similar case, in the stela TN 30.10.17.5, that it does not indicate that the stela is

( $\left.{ }^{1}\right)$ H. Ranke, PNI, 308, 14, 310; for two women had the same name from a stela acquired in Luxor, see: S. Bosticco, Le stele Egiziane dall' Antico al Nuova Regno, I, Roma, 1959, p. 21-22, fig. 14 (Florence 7590).

$\left({ }^{2}\right)$ For these water pots, see: G. Steindorff, Grabfunde des Mittleren Reichs in den Königlichen Museen zu Berlin, I. Das Grab des Mentuhotep, Berlin, 1896, p. 42; for examples from the Middle Kingdom with the same type of table and pots, see: L. Borchardt, op. cit., II, Pl 80 (CCG 1597); H. Lange \& H. Schäfer, op. cit., IV, PLs XXV (CCG 20343), LXXXII (CCG20462); without table, see: Ibid., Pls XLI (CCG 20615); with table and stoppers, see: H. Selim, op. cit., pp. 320-322, figs. 1-3; S. Bosticco, op. cit,. pp. 17, 21, figs. 7 (Florence 6369), 14 (Florence 7590).

$$
0 . .
$$


forged but rather one that shows a local artistic style which belongs to the Intermediate Period of Egypt ${ }^{(1)}$. However, I would like to suggest, based on the comment of H. Selim himself, that the stela reflects a local style of an area rather than an artistic style of Intermediate Period of Egypt ${ }^{(2)}$.

\section{Who Are the People in the Stela?}

In the stela under study, the number of people have no discoverable relationship with each other. I suggest that the owner of the stela is the man whose name is Iqbr (assuming that the feminine ending in imAxt is incorrect), and that the woman who is standing behind and clasping his hand is his wife.

\section{Date:}

The general style, the epigraphy and the iconography date the stela back to the Twelfth Dynasty, but no later than the reign of Amenemhat III, according to C. Bennett and later refined by H. Satzinger ${ }^{(3)}$. There are other criteria from the same categories and others as follow:

1- The general painting style which belongs to the colorful Theban group from the late Eleventh and early Twelfth Dynasty ${ }^{(4)}$.

2- The writing of Osiris without determinative ${ }^{(5)}$.

3- The occurrence of Osiris epithet nb @ Cddw, and the writing of $\odot d w$ with the reduplication of the sign (1)

( $\left.{ }^{1}\right)$ H. Selim, op. cit., p. 323.

( ${ }^{2}$ Ibid., pp. 328-329; cf. R. Freed, op. cit., p. 299 ff.

$\left({ }^{3}\right)$ See footnote $n^{\circ} 6$.

$\left({ }^{4}\right)$ See footnote $n^{\circ} 2$.

$\left({ }^{5}\right)$ See note (b). 
4- The writing of the horizontal sign $\rightleftharpoons$ in Osiris epithet $\mathrm{nTr} \quad \mathrm{aA}^{(2)}$.

5- The feminine ending ${ }^{\circ}$ after the determinative ${ }_{\text {in }}$ (๑)dw and $\mathrm{AbDw}^{(3)}$.

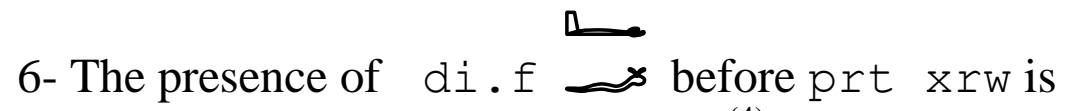
attributed to the Twelfth Dynasty ${ }^{(4)}$.

7- The appearence of the Ss mnxt $\Perp \gamma_{\text {is may be }}$ prior to the reign of Senwosret III ${ }^{(5)}$.

8- The appearence of the whole phrase $x t$ nbt nfrt wabt anxt $n \operatorname{Tr}$ (i) $m$ for the first time is attested during the beginning of the Twelfth Dynasty $^{(6)}$.

9- The standing human figures in general and the elongated skull of males in cap wigs are attested from the end of reign of Senwosret $I^{(7)}$.

10- The loose distribution of the offerings, the horizontal group of conical loaves of bread, the wide variety of jars particularly those with ovoid shapes and four water pots are attested frequently in the Twelfth Dynasty ${ }^{(8)}$.

$\left({ }^{1}\right)$ See note (c).

$\left({ }^{2}\right)$ See note $(\mathrm{e})$.

$\left({ }^{3}\right)$ See notes (c), (f).

$\left({ }^{4}\right)$ See not (g).

$\left({ }^{5}\right)$ See note (i).

$\left({ }^{6}\right)$ See note $(j)$.

${ }^{7}$ ) See footnotes $n^{\circ} 2,20$.

${ }^{8}$ ) See footnotes $n^{\circ} 26-33$. 


\section{Provenance:}

I suggest that the provenance of our stela is probably Rizeiqat or Gebelein more than Moaalla ${ }^{(1)}$. This viewpoint has been adopted based on the study of three identical stelae from the end of the Twelfth or the Thirteenth Dynasty by H. Selim ${ }^{(2)}$, who compared them them with a number of other corpus of thebean stelae, some of which are from Rizeiqat or Gebelein ${ }^{(3)}$. Accordingly, the stela under study can be classified with them, with the exception of the preceding date according to the following elements:

1- The absence of inty imntyw from the titles of Osiris $^{(4)}$.

2- The motif of smelling lotus, which is attested from the reign of Pepy II to the end of the Eleventh Dynasty, dose not appear on any dated stelae during the reign of Amenemhat I or Senwosret $\mathrm{I}^{(5)}$.

The following table shows the similarities between the stela under study and some other stelae that are probably from the same provenance.

$\left.{ }^{1}\right)$ For Moaalla see: L. Borchardt, op. cit., p. 176. For more about all three sites which located in the Theban area, see: W. Heck, Die altägyp-tische Gaue, Wiesbaden, 1974, pp. 78-81.

$\left(^{2}\right)$ See footnotes $n^{0} 10$.

$\left(^{3}\right)$ H. Selim, op. cit., p. 329, n.27-28.

$\left({ }^{4}\right)$ C. Bennett, op. cit., pp. 80-81; H, Satzinger, op. cit., p. 185.

$\left(^{5}\right)$ From the time of Amenemhat II onwards, men and women represented again smelling lotus. H. Selim, op. cit., p. 329. 


\begin{tabular}{|c|c|c|c|c|c|c|c|c|c|c|c|c|}
\hline$\sim$ & 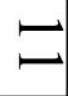 & 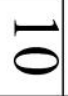 & 6 & $\infty$ & $\checkmark$ & a & U & $A$ & $\omega$ & $N$ & 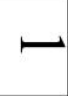 & $Z_{0}$ \\
\hline 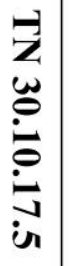 & $\begin{array}{l}\vec{z} \\
\mathbf{Z} \\
\dot{\infty} \\
\underset{i}{\mathbf{N}} \\
\underset{i}{\mathbf{w}}\end{array}$ & 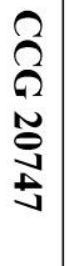 & 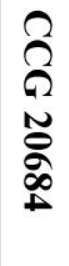 & 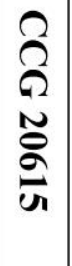 & 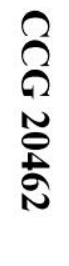 & 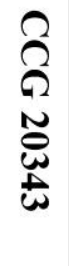 & $\begin{array}{l}2 \\
\mathcal{R} \\
\tilde{N} \\
\underset{\mathbb{N}}{N}\end{array}$ & 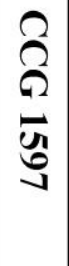 & 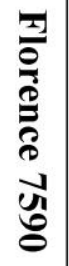 & 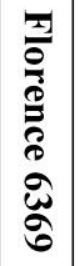 & 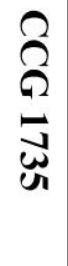 & $\frac{\mathscr{D}}{\frac{\theta}{9}}$ \\
\hline$<$ & $<$ & $<$ & $<$ & & $<$ & $<$ & $<$ & $<$ & $<$ & & $<$ & ro \\
\hline & & & $<$ & $<$ & $<$ & $<$ & $<$ & $<$ & & $<$ & $<$ & $\frac{5}{9}$ \\
\hline$<$ & $<$ & & $<$ & $<$ & $<$ & $<$ & $<$ & $<$ & & $<$ & $<$ & $\begin{array}{l}\mathcal{Z} \\
\& \\
2\end{array}$ \\
\hline & & & & $<$ & & & $<$ & $<$ & & & $<$ & $\begin{array}{lll}0 & 1 \\
1 & 0 & 0 \\
w & 0\end{array}$ \\
\hline$<$ & $<$ & & $<$ & $<$ & $<$ & $<$ & $<$ & $<$ & & & $<$ & \\
\hline$<$ & $<$ & & $<$ & $<$ & & $<$ & $<$ & $<$ & $<$ & $<$ & $<$ & $\stackrel{R}{i}$ \\
\hline$<$ & & & $<$ & & & & $<$ & & & & $<$ & $\begin{array}{l}2 x \\
\Sigma\end{array}$ \\
\hline$<$ & & & $<$ & $<$ & & $<$ & & & & & & 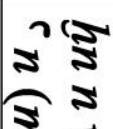 \\
\hline$<$ & $<$ & $<$ & $<$ & $<$ & $<$ & $<$ & $<$ & $<$ & $<$ & $<$ & $<$ & $\underset{m}{\infty}$ \\
\hline
\end{tabular}




\begin{tabular}{|c|c|c|c|c|c|c|c|c|c|c|c|c|}
\hline 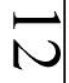 & ש & $\varpi^{\circ}$ & 6 & $\infty$ & $\checkmark$ & o & U & $D$ & $\omega$ & $N$ & — & $Z_{0}$ \\
\hline 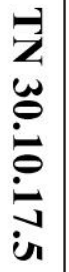 & 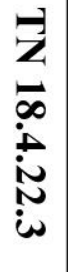 & 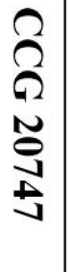 & 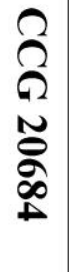 & 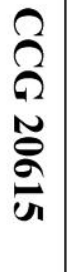 & 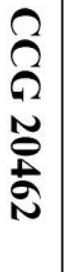 & 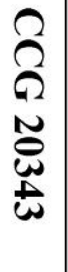 & 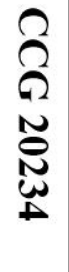 & $\stackrel{2}{\overparen{R}}$ & 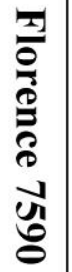 & 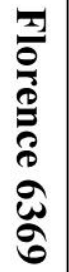 & 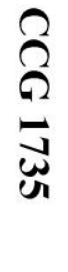 & $\frac{\mathscr{D}}{\frac{\vec{D}}{\theta}}$ \\
\hline$<$ & $<$ & & $<$ & $<$ & & & $<$ & $<$ & $<$ & & $<$ & r \\
\hline$<$ & $<$ & $<$ & $<$ & $<$ & $<$ & & $<$ & $<$ & $<$ & $<$ & $<$ & 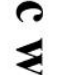 \\
\hline$<$ & $<$ & $<$ & $<$ & $<$ & & $<$ & $<$ & $<$ & $<$ & $<$ & $<$ & $\frac{\mathbf{E}}{8}$ \\
\hline$<$ & $<$ & $<$ & & $<$ & & & $<$ & $<$ & $<$ & & $<$ & $\pi$ \\
\hline & & & & & & $<$ & $<$ & $<$ & $<$ & & $<$ & $\begin{array}{l}\xi \\
\xi\end{array}$ \\
\hline & & $<$ & & & & & & & & $<$ & $<$ & $\vec{B}$ \\
\hline$<$ & $<$ & $<$ & $<$ & $<$ & $<$ & $<$ & & $<$ & $<$ & $<$ & $<$ & o \\
\hline & & & & $<$ & $<$ & $<$ & $<$ & & $<$ & $<$ & $<$ & 2 \\
\hline$<$ & $<$ & & $<$ & $<$ & $<$ & & $<$ & $<$ & $<$ & $<$ & $<$ & $\vec{z}$ \\
\hline
\end{tabular}


(A) Table Abbreviations:

\begin{tabular}{|c|c|c|c|}
\hline p s & painting style & $\mathbf{r} \mathbf{b}$ & rectangular base \\
\hline $\mathrm{nHd}$ & $\mathrm{nsw}+\mathrm{Htp}+\mathrm{di}$ & $\mathbf{c} \mathbf{w}$ & cap wig \\
\hline $\mathbf{w} \mathbf{w} \mathbf{d}$ & $\begin{array}{l}\text { Wsir } \\
\text { without } \\
\text { determinative }\end{array}$ & u e & uncovered ear \\
\hline $\begin{array}{l}\mathbf{F e} \\
\text { @) } \& \\
\mathbf{A}\end{array}$ & $\begin{array}{l}\text { feminine ending of } \\
\text { Codw \& AbDw }\end{array}$ & $1 \mathbf{k}$ & long kilt \\
\hline$h \rightleftharpoons$ & horizontal sign & $\begin{array}{c}\mathbf{w} \mathbf{w} \\
\mathbf{l}\end{array}$ & $\begin{array}{l}\text { wig } \quad \text { without } \\
\text { lappet }\end{array}$ \\
\hline d. $f$ & $\begin{array}{l}\text { di. f before prt } \\
\text { xrw }\end{array}$ & $\begin{array}{c}\mathbf{f} \mathbf{m} \\
\mathbf{a}\end{array}$ & $\begin{array}{l}\text { floating in } \\
\text { midair }\end{array}$ \\
\hline $\mathrm{S} \mathrm{m}$ & 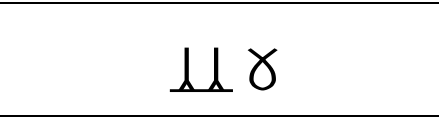 & lod & $\begin{array}{l}\text { loose offerings } \\
\text { distribution }\end{array}$ \\
\hline $\begin{array}{ll}x & n \\
n & w \\
a & n \\
(m)\end{array}$ & $\begin{array}{lll}\text { xt } & \text { not } & \text { nfrt } \\
\text { wabt } & \text { nTr } & \text { (i)m }\end{array}$ & c l & conical loaves \\
\hline $\mathbf{s h f}$ & $\begin{array}{l}\text { standing human } \\
\text { figures }\end{array}$ & f w p & four water pots \\
\hline
\end{tabular}

(B) Table References:

\begin{tabular}{|c|c|c|c|}
\hline $\mathbf{N}^{\mathbf{0}}$ & References & $\mathbf{N}^{\mathbf{0}}$ & References \\
\hline 2 & See footnote $n^{\circ} 38$ & 8 & See footnote no 25 \\
\hline 3 & See footnote no 38 & 9 & See footnote $n^{\circ} 10$ \\
\hline 4 & See footnote $\mathrm{n}^{0} 18$ & 10 & See footnote $\mathrm{n}^{0} 25$ \\
\hline 5 & See footnote $\mathrm{n}^{\circ} 10$ & 11 & See footnote $n^{\circ} 10$ \\
\hline 6 & See footnote $n^{\circ} 38$ & 12 & See footnote $n^{\circ} 10$ \\
\hline 7 & See footnote $n^{\circ} 38$ & & \\
\hline
\end{tabular}




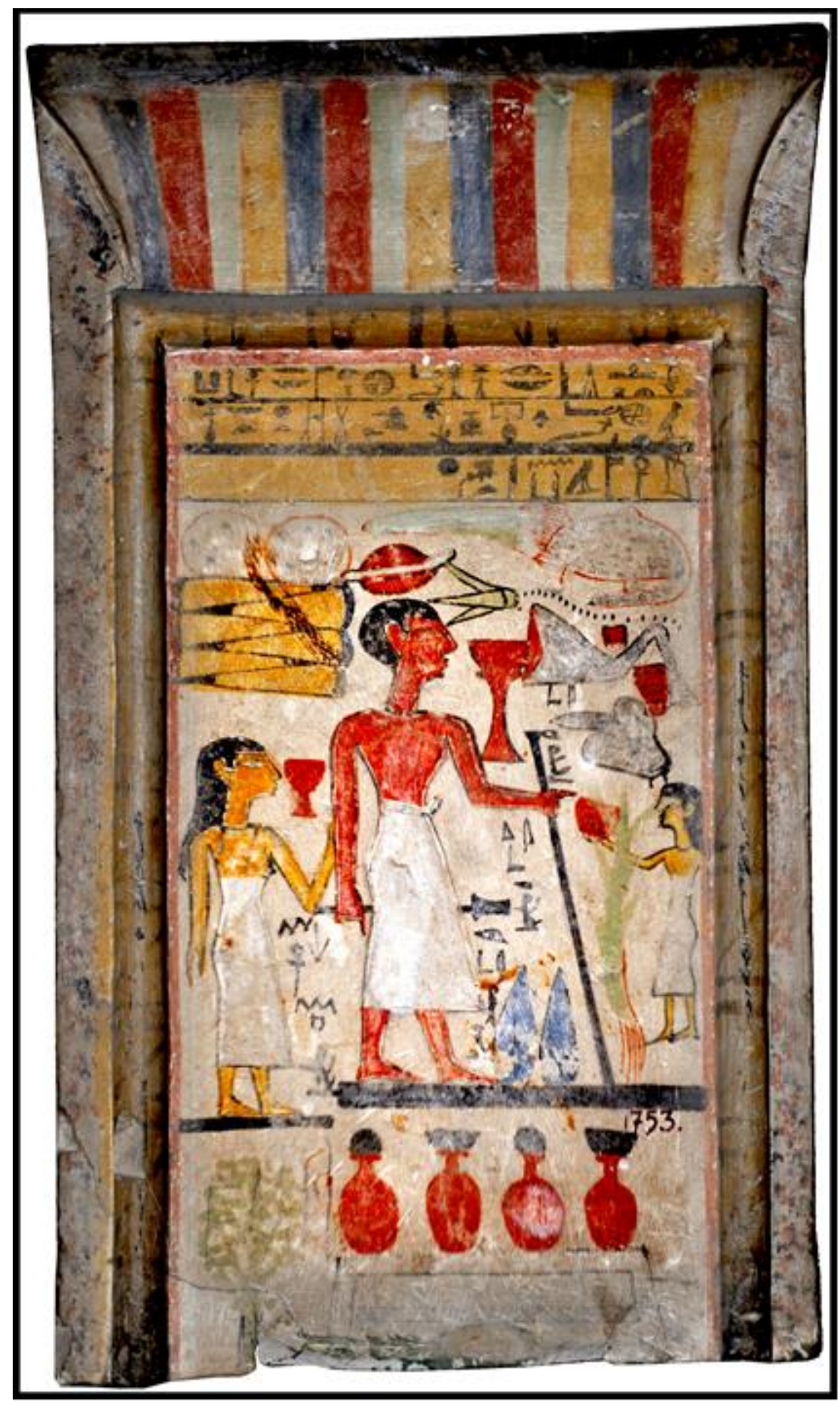

$0 . V$ 
Plate (1)

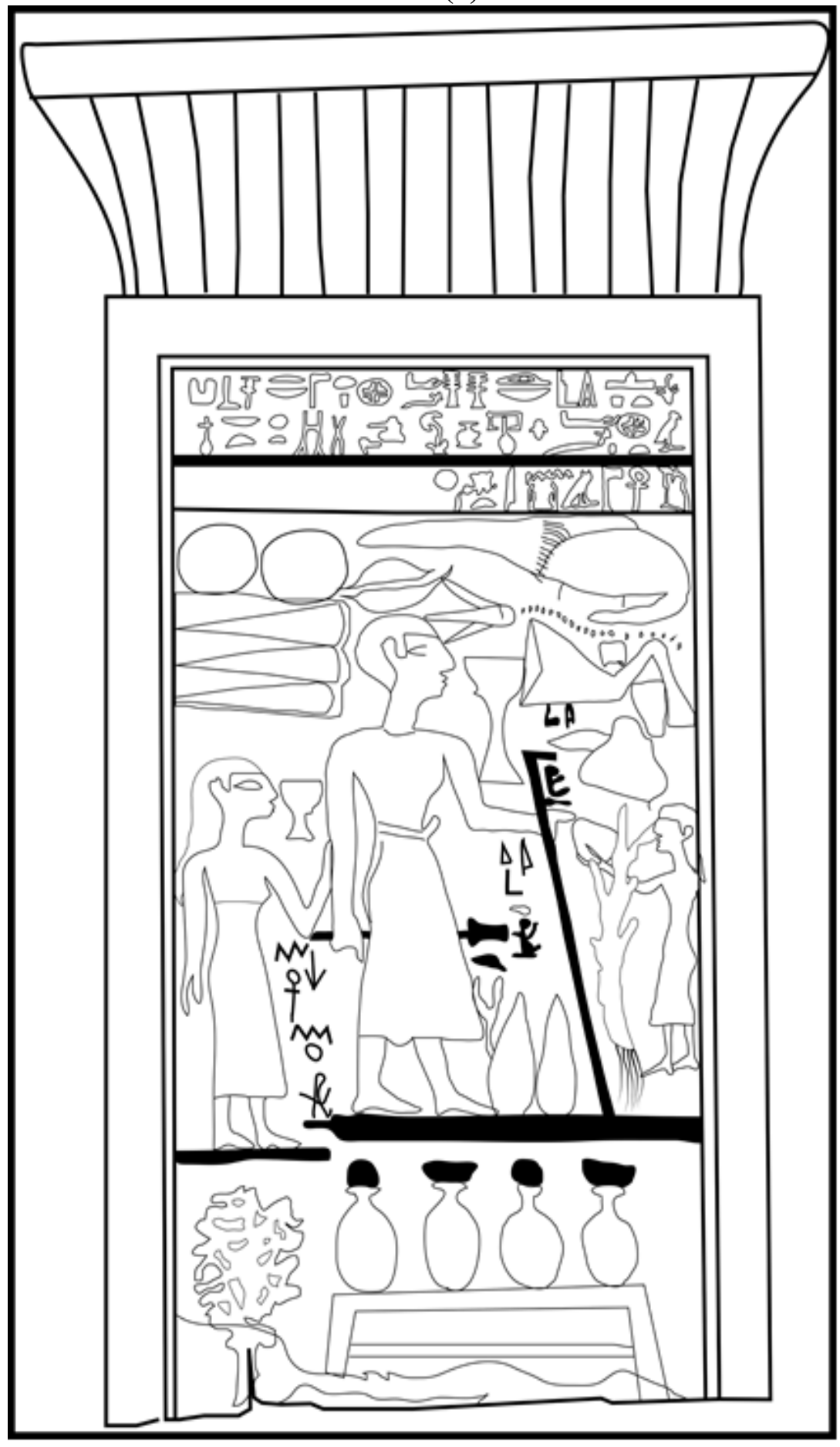

0.1 
مجلة كلية التربية ـ جامعة الإسكندرية المجلد الساد والعشرون (العدد الثاني) لسنة 17 ـ ب

Figure (1)

0.9 